Jpn. J. Hosp. Pharm.

$\left[\begin{array}{l}\text { 堀 } \\ 19(5) 450-457 \text { (1993) }\end{array}\right]$

\title{
外来㭧者における吸入液の使用実態調査
}

\author{
杉山一覚*, 柿㠃正子, 浅見博子, 高田洋子, 戸張敬子, 松本富夫, 建部 守 \\ 獨協医科大学越谷病院薬剤部门
}

\section{An Investigation of Use of Inhalant Solution for Outpatients}

\author{
IKKAKU SUgIYAMA*, MASAKO KAKIZAKI, HiROKO ASAMI, \\ YOKO TAKADA, KEIKO TOBARI, \\ TOMio MATSUmoto, MAMORU TATEBE \\ Department of Pharmacy, Koshigaya Hospital, \\ Dokkyo University School of Medicine†
}

( $\begin{aligned} & \text { Received June 3, } 1993 \\ & \text { Accepted July 6, 1993) }\end{aligned}$

\begin{abstract}
We queried by questionnaire the outpatients who were taking inhalant solutions were prepared in our hospital about how they were using these solutions. As the result, we found that it was generally difficult for a patient to handle a nebulizer hygienically. Accordingly, we believe that it is necessary to research the stability of the constituent as well as the microbial contamination after the prepared inhalants are handed to the patients. As the conclusion of our research, we plan to prepare a leaflet that demonstrates how to handle prepared inhalant solutions correctly.
\end{abstract}

Keywords_questionnaire to outpatients; inhalant solution; nebulizer; stability of the constituent; microbial contamination

\section{はじめに}

呼吸器疾患の治療にネブライザーを用いての吸 入療法がある。しかし，吸入液の使用の実態はほ とんど調査されていないのが現状である.

当院では, 医師からの処方せんにより, 吸入液 を薬剤師が調製して患者に交付している. そこ

で，著者らは当院で調製された吸入液を使ってい る外来患者を対象に, 吸入方法, 保存方法等につ いてアンケート調査を行ったので，ここに報告す る.

†越谷市南越谷2-1-50；2-1-50 Minami-koshigaya， Koshigaya, 343 Japan
方法

調查期間 1990 年 9 月 25日〜 10月 8 日

対象者 当院で調製された吸入液が処方され ている外来患者 28 名（表 1)

回収率 $100 \%$

表 1. 対象者内訳

\begin{tabular}{c|c|c|c}
\hline 年 齢 & 男 性 & 女 性 & 計 \\
\hline 3 歳 16歳 & 3 & 6 & 9 \\
\hline 42 歳 82歳 & 13 & 6 & 19 \\
\hline 計 & 16 & 12 & 28 \\
\hline
\end{tabular}

質 問 事 項 
表 2.

\section{アンケートに御協力下さい}

このたび，薬剤部で調製された吸入薬を。患者さんがより使い易いように改善するため, 薬剤部で資料を 作成することになりました。つきましては，患者さんがどのよう御使用になっているかを調査させていた だきたいと思いますので，以下の質問に扮答え下さい。

該当するものに○をつけて下さい。

【1】拓使いになっている吸入用器械について招尋ねします。

1. 器械の種類はどれですか.

a.

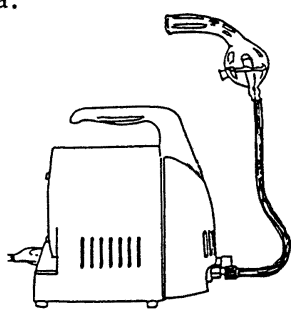

b.

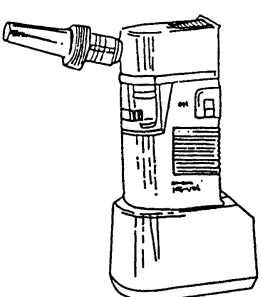

c.

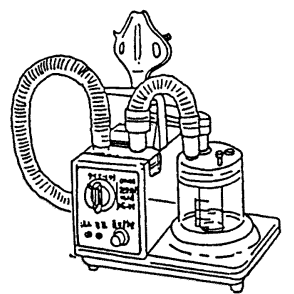

d.

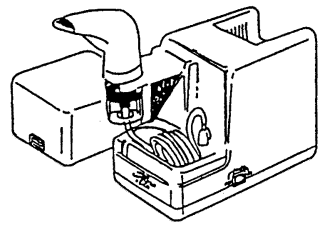

2. 器械のおそうじをしていますか.

している していない

していると答えた方に

a.どのくらいの間隔でおそうじをしていますか。

使ったあと毎回 1 日 1 回 1 日执き その他（）

b．どのような方法でおそうじしていますか。

煮沸消毒 消毒液につける 水洗いのみ その他（）

【2】吸入方法について搡ねします。

1. 吸入方法はどのように知りましたか.

医師看護婦 薬剤師 器械の説明書 その他（）

2. 1 日何回使っていますか。

1 回 2 回 3 回 4 回 それ以上 決まっていない衤の他（）

3. いつ使っていますか.

起床時 朝 昼夕寝る前 発作時 その他（）

4. ぞのくらいの時間, 吸入をしていますか.

指示された量の薬がなくなるまで（約

分） 症状が落ち着くまで（約

分）

【3】調製された吸入薬について打尋ねします。

1. 抢薬はどこに置いていますか.

冷蔵庫冷蔵庫以外の場所（具体的に ）

2. 打薬をはかっている道具はどれですか.

計量カップ 注射筒 その他（具体的に ）

3. はかった道具は使ったあとどうしていますか.

そのまますぐ洗う次に使う前に洗う その他（）

4. 受け取った䍒は, 何日位で使い切りますか。（）日位

5. 扣薬が次回来院するまでに余った時どうしていますか。

捨ててしまら使い切ってから新しいものを使うその他（）

【4】吸入薬を技使いになっていて困った事，わからない事などがありましたら揞き下さい。

【5】吸入薬について御意見や御希望がありましたら怙書き下さい。

お忙しいところアンケートに御協力いただきましてありがとうございました。 


\section{結果および考察}

アンケートの質問事項に従い，次のような結果 を得た。

\section{〔1]吸入用器械について}

\section{1. 器械の種類について}

使用しているネブライザーの種類は a , b , c , d の順位となり，コンプレッサー式ネブライザー (a,d) $42.8 \%$ ，超音波式ネブライザー(b,c) 46.5 \%の使用率で率った。 その他に $\mathrm{a} ， \mathrm{c} の 2$ 種のネ ブライザーを購入している患者も 1 名いた.

この結果から，様々な機種が用いられているこ とがわかった。

な拈，表 2 㧊よび図 1 のネブライザー $\mathrm{a}, \mathrm{b}, \mathrm{c}, \mathrm{d}$ はそれぞれ，日商式吸入用コンプレッサーセット

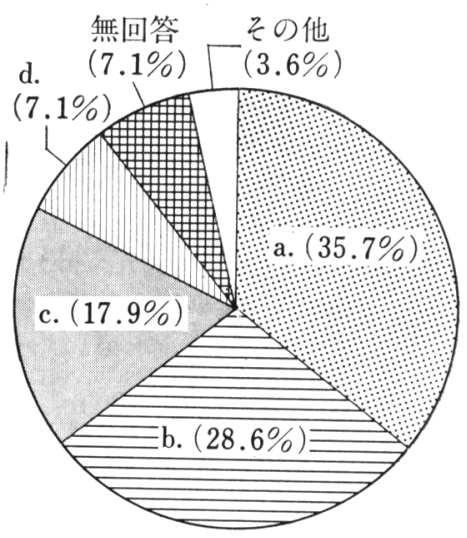

図 1 . 器械の種題

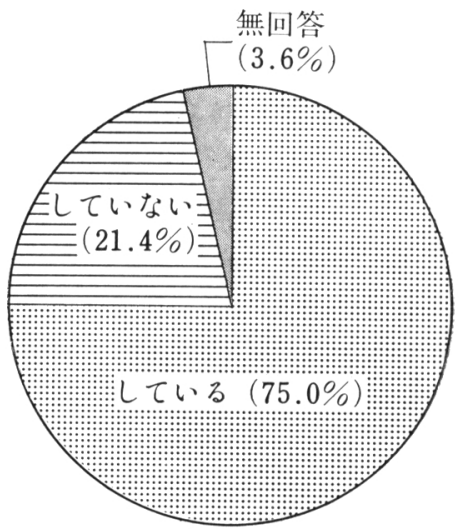

図 2. 器械の㧍去らじをしていますか
$\mathrm{A}$ 型, オムロン超音波式吸入器 $\mathrm{NE}-\mathrm{U} 06$, オム口 ン超音波式吸入器 NE-U11B，オムロンコンプレ ッサー式吸入器 NE-C11 である。

\section{2. 器械のそうじについて}

a. そうじの間隔について。

b. そらじの方法について。

全体の75\%が掃除をしていると答兄（図 2)，そ のらちの約半数の人が使用後毎回掃除をしている といらことであった（図 3 ).さらにその掃除の方 法は実に $76.2 \%$ の 人が水洗いのみであることが分 かった（図 4).

一方，21.4\%の人が掃除をしていないと答光た (図 2 ).

ネブライザーの説明書を見ると, 前述の $a, b$, c, d の 4 種類共, 使用後は良く洗浄打よび消毒を

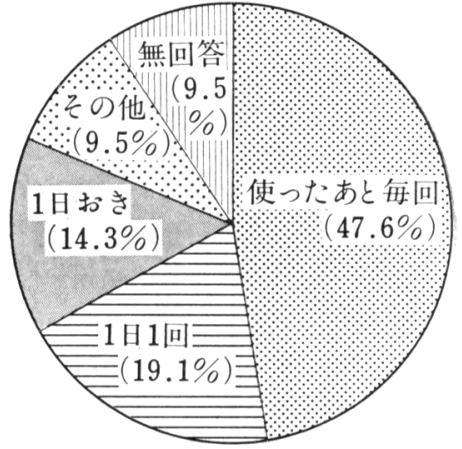

図3.どのくらいの間隔で拈去らじを していますか

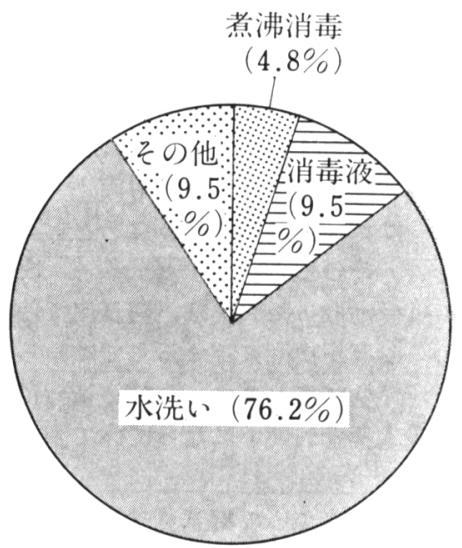

図 4.どのような方法で扔そうじを していますか 
することと記載されている，さらに $\mathrm{d}$ は惹沸消毒 ができることも記載されている。

本来, 治療を目的としているネブライザーだ が，掃除を意っていると患者の気管支や肺胞にエ アロゾルとともに大量の微生物を運ぶことにな り, 逆に呼吸器感染症をひき起こすことになりか ねない1.

しかし，ネブライザーを使用している患者は, 器械の掃除の難しさや煩わしさ, さらには医療従 事者側からの説明不足や認識不足が要因となり, 衛生的管理がなされているとはいいがたいのが現 状であった。

\section{[2]吸入方法について}

\section{1. 吸入方法をどのように知ったかについて}

淘とんどの人が医師から吸入方法を知ったと答 光た、事前に患者に対して医師または看護婦から 吸入方法についての説明がなされているようだ。

器械の説明書で吸入方法を知った之答光た人 は，複数回答があったため，図 5 では $12.5 \%$ とな っているが, 実際に器械の説明書だけで吸入方法 を知ったと答光た人は，わずか 1 名であった。

\section{1 日の使用回数について}

1 日 3 回使用する場合が最も多いのではないか と思っていたが，調査してみると，1日 2 回吸入 していると答光た人が最も多く，決むっていない と答光た人が次に多かった。全体としては，吸入 回数に明確な差は見られなかった。そこで，この 患者らの処方世九をさらに調査してみると, 決ま

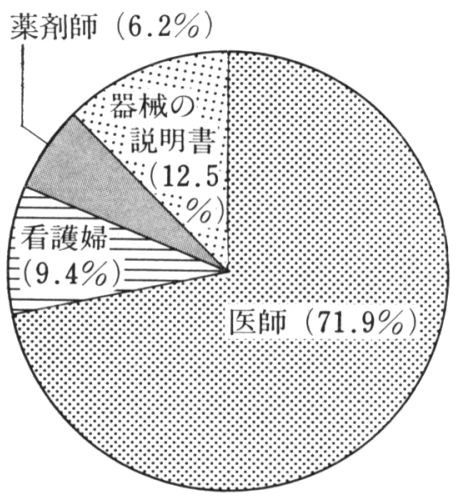

図 5. 吸入方法はどのように知りましたか （複数回答を含む）
っていないと答えた人はすべて必要時使用の処方 であった。 また，1日の回数が指示されている処 方の場合でも, 指示された回数と使用している回 数が一致していない場合がほとんどであった $(70.6 \%)$.このことは, 吸入療法が気管支喘息の 発作時あるいは発作予防等の目的で行われるた め，不定期な使用が余儀なくされるためであろ 5 .

\section{3. 使用時期について}

複数回答で答光た人が多く, 使用時期の組又合 わせは個人により異なっていた。 そこで複数回答 を, 起床時, 朝, 昼, 夕, 寝る前, 発作時, 外出 時といらょうに個々に分析してみると, 朝 (25.0 $\%$ ) 寝る前, $(19.10 \%$ ) 昼, 夕, 発作時（各々

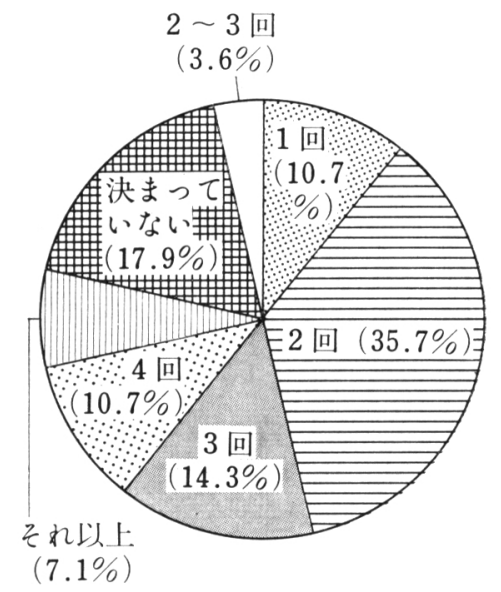

図 6. 1 日何回使っていますか

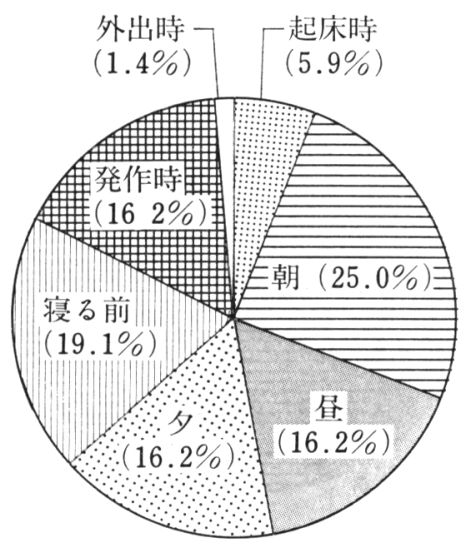

図 7. いつ使ってい屯すか（複数回答を含导） 
$16.2 \%)$ 起床時 $(5.9 \%)$ 外出時 $(1.4 \%)$ の順番 となった。

寝る前や発作時に使用すると答える人が多い上 うに思っていたが，意外飞も，使用時期に目立っ た差は見られなかった。

\section{4. 吸入時間について}

指示された量の薬がなくなるまで之答光た人は 全体の $85.7 \%$ で大半を占め，その吸入時間は 5 〜 10分之答光た人 $(41.7 \%)$ が最も多かった。また 最長吸入時間は 30 分であった。症状が落ち着くま でと答光た人は全体の $14.3 \%$ で，その吸入時間は 2 分 1 名, 5 分 1 名, 10 分 1 名, 無回答が 1 名で あった。吸入時間は薬液の量によっても，使用儿 ているネブライザーの種類によっても違いが生じ るとい觉だろう。

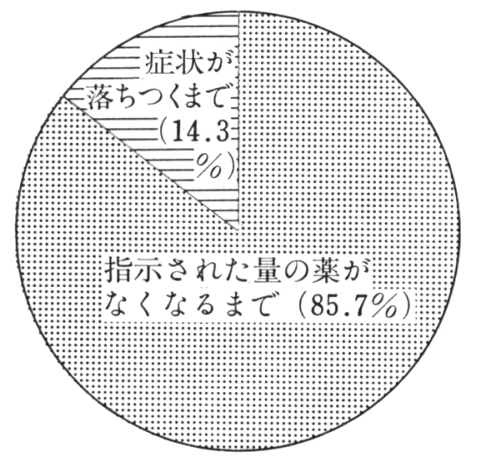

図 8.どのくらいの時間吸入をしていますか

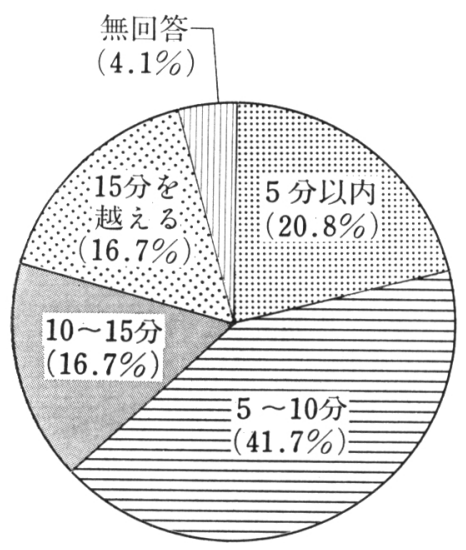

図 9. 指示された量の薬がなくなるまでと 答壳た人の吸入時間

\section{〔3〕調製された吸入薬について}

\section{1. 薬の保存場所について}

当薬剂部での患者への指示が，冷蔵庫保存にな っているにもかかわらず，冷蔵庫以外の場所，例 えば本棚などの場所に置いている患者が $14.3 \%$ い た。ここで問題となるのは, 保存剂が含有されて いない，あるい㤷有さ机ていても生食等による 希釈でその効力が十分に得られない吸入液を室温 で保存した場合, 微生物による污染の可能性が考 兄らるといらことである。

\section{2. 薬を計っている道具について}

当薬剂部で調製した吸入液に添付している計量

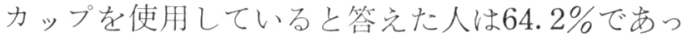
た。一方，添付していない注射筒を使用していた 人が $14.3 \%$ ，その他，目見当やスポイトを使用し

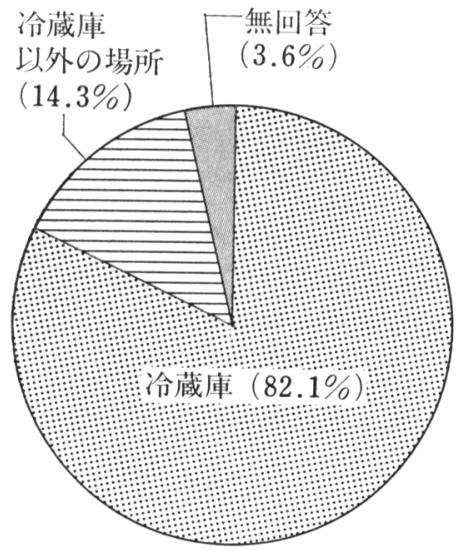

図 10. 拈薬はどこに置いていますか

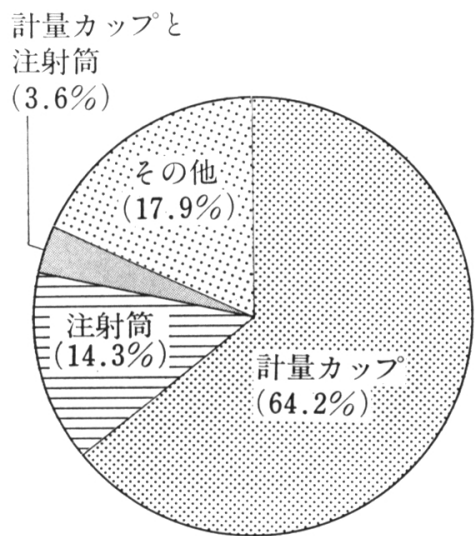

図 11. 预薬をはかっている道具はどれですか 
ている人もいた，吸入液を計量する際の注射筒の 使用はいくつかの利点もあるが取扱いや廃棄等に 問題がある、そこで，当薬剤部では特に優れてい るといら訳ではないが使用する上での簡便さとい う観点から計量カップを添付している.

\section{3. 計った道具の後処理について}

汪とんどの人がすぐ洗う $(82.2 \%)$ と答えた が，洗わずにとのままにしておく $(10.7 \%)$ と答 光たもいた。

不衛生なカップで計量して患者がネブライザー 療法を行った場合，あるいは取り過ぎた吸入液を 元の容器に戻した場合, 吸入液が微生物に污染さ れる可能性が出てくる。そこでカップは使用前に 洗い, 吸入液怓り過ぎても元の容器に戻さない

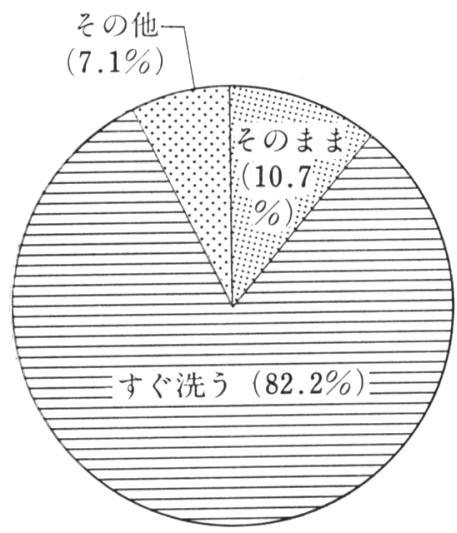

図 12. 計った道具は使ったあと どうしていますか

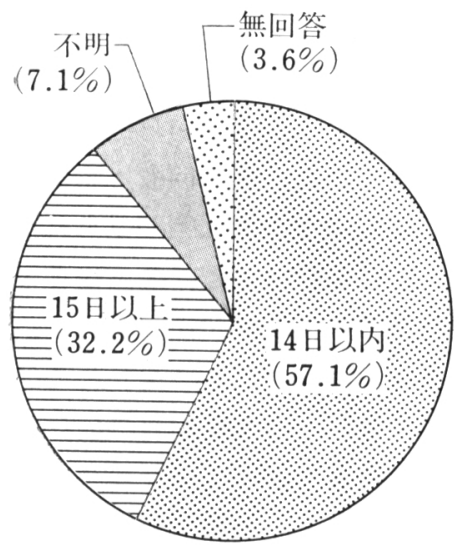

㘠 13. 受け取った挴薬は何日ぐらいで 使い切りますか
ように，患者に指導する必要があるだろう。

\section{4. 受けとった薬の使用期間について}

14 日之答光た人が $57.1 \%$ と最も多く，之机以上 であると答光た人は $32.2 \%$ であった。最長は， 1 〜3か月であった.

開院以来当薬剂部では, 調製の必要な吸入液は 14日分を目安に処方するよう医師に颃願いしてい る。そのため通常は14日以内の処方となる場合が 多いが，医師あるいは患者の都合により14日を越 光る処方も時折見受汁られる。個々のアンケート 結果之処方内容を照会してみると, 処方日数が記 載されている場合は，その処方日数以内に使い切 っている場合が淘とんどであった (82.4\%).乙か し必要時使用の指示がある場合は，処方日数が記 載されている場合よりも，使用期間が長いという 結果が得られた。

\section{5. 次回来院するまでに余った薬の取扱いにつ} いて

捨ててしまうと答光た人と使い切ってから新し いものを使らと答光た人は，それぞれ $46.4 \%$ そ市 った.

ここで先程の設問〔3 3 〕 4 と合わせて考学て みると, 一旦患者の手に渡り, 使い始めた吸入液 を長期間かか⿰て使い切る場合（最長 3 か月と答 えた人がいた),この間の患者の取扱いや保存状態 により, 吸入液の品質（成分の安定性や微生物に よる污染など）が保たれているかどうか疑問が残

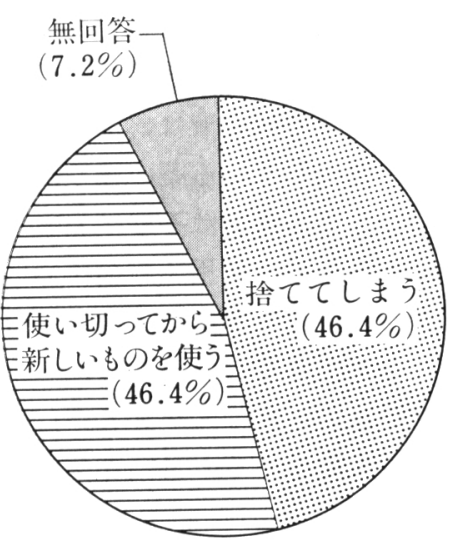

図 14. 敊薬が次回来院するまでに余った 時はどうしていますか 
る.このことから吸入液を患者に渡す時には，吸 入液の取扱い方法や保存方法，さらにはある一定 期間が過ぎたら，その吸入液は廃棄するなどの基 準を設けた注意書を添付する必要があるのではな いかと思われる.

〔4〕吸入液を使っていて困った事，わからな

\section{い事などについて}

回答者は 5 名であった，その中の 1 名は，使用 後毎回水洗いしているにもかかわらず，時々薬が つまると答えた。ネブライザーの手入れは難しい ものなのだろら。また計量がうまくできない（1 名), こぼして足りなくなる（1名）という回答が あった。そこで実際に我々が吸入液をカップで計 量してみたところ，この意見になるほどうなづけ た.

さらに，外出時に吸入液を携帯し，帰宅後冷蔵 庫に戻すようにしているが，入れたり出したりし て大丈夫なのかといら質問をした人が 1 名いた.

これはネブライザーを使用している患者にとって は切実な問題だと思う．現在非常にコンパクトな ネブライザーも市販されているので, 最小限必要 な吸入液と共に携帯する方法もある。しかしなが ら調製された吸入液の品質を考慮すると外出時は やはり別にハンドネブライザーを携帯するのが最 も適切ではないだろうか.

その他に薬があわないので变更して欲しいとい ら意見があった。括そらく医師に直接薬の相談は しづらかったのだろう。

\section{〔5〕吸入液についての意見や希望について}

回答者は 4 名であった。病院で使用している吸 入液と家で使用する吸入液は異なるのかという人 が 1 名いた. 使用している薬の種類が事前に医師 から説明がなくこの患者は不安に思っているよう だ. 患者はあらかじめ使用する薬についての説明 を受けることによって余分な不安を多少なりとも 取り除くことができるのではないだろうか，その 他に使用感が良いと言う人が 2 名いた。 もら少し 日持ちする吸入液があると良いと言う人が 1 名い た.

調製された吸入液は原測として品質を考慮して 14日までと院内で取り決めているので，患者はお
のずと14日ごとの来院を強いられることになる. 従って, 日持ちする吸入液を望む声があるのも当 然だと思う。我々は調製された吸入液の安全性を 十分検討した上でこのような患者の要望に応えて いきたいと思う。

おわりに

本調査は，当院で調製した吸入液が処方せんで 交付されている外来患者のみを対象に 2 週間行っ た.

調査に当たっては，事前に，吸入液が処方され る外来患者が, 最も多く来院する日を調查し，そ の期間に合わせてアンケート調査を行った．対象 となる吸入液が交付されている外来患者の数は, 28名となり，母集団は，小さなものとなってしま った。しかしこれは調查当時, 調製された吸入液 が外来で交付されている患者の約 8〜9割に相当 していたので, 今回は業務の都合上ここまでとし た.なお，1990年 $9 ， 10$ 月の一日平均来院患者数 は, 約1200名であった。調査開始前は不安もあっ たが，非常に丁寧な回答が得られたことに感謝す ると共に，患者およびその家族が自分達の健康に 強い興味を抱いているということに驚きを感じ た.

各設問の結果には，それぞれ若干のコメントを 付けたが総括すれば次のよらになる.

1）外来患者の使用している吸入用ネブライザ 一の種類は，まちまちであった：ほとんどの人が 掃除をしていると答えたが，その方法の多くは， 水洗いであった.

2）ほとんどの人が医師から吸入方法について の説明を受けていた. 吸入回数, 時期, 時間は特 に決まった傾向はなく個人差が見られた。

3）吸入液の保存は主に冷蔵庫保存で, 計量に は当薬剤部添付のカップが使用されていた。また そのカップは使用後ただちに洗われていた。吸入 液は調製後半数以上の人が14日以内に使用してい た. 次回来院時まで余っていた場合は, 捨ててし まう人と使い切ってから新しい物を使う人が半々 だった。

以上，調查を終えて，吸入用ネブライザーを衛 
生的に管理していくのは患者にとって難しいこと だと思った。また，当薬剤部で調製された吸入液 が患者の手に渡った後も安全に使用されるよう に, 成分の安定性ならびに微生物による污染の調 査をし,さらに患者向け指導書を作成していく必
要があると感じた。

\section{引用文 献}

1）尾家重治, 神代 昭, 医学のあゆみ, 141，27 (1984). 